Article

\title{
Application of SWAT Model with CMADS Data to Estimate Hydrological Elements and Parameter Uncertainty Based on SUFI-2 Algorithm in the Lijiang River Basin, China
}

\author{
Yang Cao ${ }^{1,2}$, Jing Zhang ${ }^{1, *}$, Mingxiang Yang ${ }^{3}$, Xiaohui Lei ${ }^{3}$, Binbin Guo ${ }^{1}$, Liu Yang ${ }^{2}$, \\ Zhiqiang Zeng ${ }^{3}$ and Jiashen $Q u^{4}$ \\ 1 Key Laboratory of 3D Information Acquisition and Application of Ministry of Education, Capital Normal \\ University, Beijing 100048, China; m171892@hiroshima-u.ac.jp (Y.C.); guobinbin@126.com (B.G.) \\ 2 Graduate School of Integrate Arts and Sciences, Hiroshima University, Hiroshima 7398521, Japan; \\ g170292@hiroshima-u.ac.jp \\ 3 China Institute of Water Resource and Hydropower Research, Beijing 100038, China; \\ yangmx@iwhr.com (M.Y.); lxh@iwhr.com (X.L.); zengzhiqiang@hust.edu.cn (Z.Z.) \\ 4 Graduate School of Education, Hiroshima University, Hiroshima 7398521, Japan; jackykutsu@yahoo.com \\ * Correspondence: maggie2008zj@yahoo.com; Tel.: +010-68903139
}

Received: 29 March 2018; Accepted: 4 June 2018; Published: 7 June 2018

\begin{abstract}
The China Meteorological Assimilation Driving Datasets for the Soil and Water Assessment Tool model (CMADS) have been widely applied in recent years because of their accuracy. An evaluation of the accuracy and efficiency of the Soil and Water Assessment Tool (SWAT) model and CMADS for simulating hydrological processes in the fan-shaped Lijiang River Basin, China, was carried out. The Sequential Uncertainty Fitting (SUFI-2) algorithm was used for parameter sensitivity and uncertainty analysis at the daily scale. The pair-wise correlation between parameters and the uncertainties associated with equifinality in model parameter estimation were investigated. The results showed that the SWAT model performed well in predicting daily streamflow for the calibration period (2009-2010). The correlation coefficient $\left(\mathrm{R}^{2}\right)$ was 0.92 , and the Nash-Sutcliffe model efficiency coefficient (NSE) was 0.89. For the validation period (2011-2018), $R^{2}=0.89$, $\mathrm{NSE}=0.88$, and reasonable values for the P-factor, R-factor, and percent bias (PBIAS) were obtained. In addition, the spatial and temporal variation of evapotranspiration (ET), surface runoff, and groundwater discharge were analyzed. The results clearly showed that spatial variation in surface runoff and groundwater discharge are strongly related to precipitation, while ET is largely controlled by land use types. The contributions to the water budget by surface runoff, groundwater discharge, and lateral flow were very different in flood years and dry years.
\end{abstract}

Keywords: SWAT model; CMADS; Lijiang River; runoff; uncertainty analysis; hydrological elements

\section{Introduction}

The water cycle is one of the most important of the earth's cycles, and it plays a crucial role in biosphere changes. Water balance elements in a basin are affected by natural and human factors, such as the types of land use, soil properties [1], geological conditions, glacier [2] and human economic activity [3,4]. It is necessary to study the contribution to the water budget by different hydrological elements in a basin for the purpose of land use management, water resources management, and hydrological process analysis. Because the contribution to the water budget by different hydrological elements is hard to measure in the field, it is more practical to estimate the water cycle components of a watershed using a hydrological model [5]. 
The Soil and Water Assessment Tool (SWAT) model is an important tool in the development of water management strategies [6]. At the beginning of SWAT model establishment, it is difficult to calculate the water cycle components, especially groundwater [7]. Sophocleous et al. [8] simulated combined surface-water, ground-water, and stream-aquifer interactions using a comprehensive SWATMOD basin model, which was based on the Modular Three-Dimensional Finite-Difference Ground-Water Flow Model (MODFLOW). Because the SWAT model was established using the characteristics of a North American river basin, the accuracy of the model can be compromised in other areas. For example, the SWAT99.2 version could not satisfactorily calculate the runoff in low mountain regions of Germany. To address these shortcomings, Eckhardt et al. $[9,10]$ developed the SWAT Giessen (SWAT-G) version for simulating the runoff in catchments with predominantly steep slopes, shallow soils, and consolidated rock aquifers. In addition, Easton et al. [11] established a Soil and Water Assessment Tool-Variable Source Area (SWAT-VSA) model for predicting runoff by modifying the curve number and available water content in variable source areas.

Although the SWAT hydrological model has been widely used for nutrient transport and hydrological modeling, the model is difficult to apply in areas where meteorological data are scarce, such as glacial and deserts areas [12]. Therefore, meteorological data are urgently needed for runoff simulation and prediction in non-data basins [13]. The CMADS was developed by Dr. Xianyong Meng from the China Institute of Water Resources and Hydropower Research (IWHR). The data range is from 2008 to 2016. It covers the entire East Asian region [14]. Some studies considered that CMADS+SWAT have better results for runoff simulation [15,16]. Meng et al. [17] evaluated the water cycle in an area without meteorological data using the CMADS meteorological data. They obtained satisfactory results through parameter calibration in areas with a high glacial recharge rate. Meng et al. also used three different datasets to simulate runoff in the Heihe Basin, and the results showed that the simulation accuracy of the CMADS was higher than other datasets [18]. The uncertainty analysis based on CMADS data has also been investigated [19]. In recent years, SWAT has been successfully applied in the study of hydrological elements in various watersheds. For example, the SWAT model was applied to study changes in the water budget caused by climate change [20-23]. The SWAT model was used to study hydrological elements in ice- and snow-covered mountainous area [24-26]. The SWAT model has also been used to study the main hydrological elements in agricultural areas [27-29].

Although the CMADS data have been applied worldwide since its release in 2016, the application of CMADS in abundant rainfall areas in southern China is lacking [30]. Further investigations of the applicability of the CMADS in the SWAT model are needed to better understand and evaluate the accuracy and efficacy of the dataset. The Lijiang River is an important water system in the Pearl River Basin, and the CMADS data have not been verified in this basin. To address this knowledge gap, the present study applied the SWAT model to explore the applicability of the CMADS in this basin. The Sequential Uncertainty Fitting (SUFI-2) algorithm was used for parameter sensitivity and uncertainty analysis at a daily scale. Pair-wise correlation between parameters and the uncertainties associated with equifinality in model parameter estimation was also investigated. The simulation results were used to investigate the water budget and its elements in the basin. The study also investigated the spatial variation and temporal variation of the water budget elements. In addition, the correlation between hydrological elements and precipitation were investigated.

\section{Materials and Methods}

\subsection{Study Area}

The Lijiang River Basin $\left(23^{\circ} 23^{\prime}-25^{\circ} 59^{\prime} \mathrm{N}, 110^{\circ} 18^{\prime}-111^{\circ} 18^{\prime} \mathrm{E}\right)$ is located in the northeast of the Guangxi Province, within the upper reaches of the Guijiang River in the Pearl River system (Figure 1). From north to south, the basin runs through Xingan County, Lingchuan County, Guilin City, Yangshuo County, and Pingle County. The total area of the basin is about $6050 \mathrm{~km}^{2}$, and the climate is characterized by high temperatures and rainfall in summer, cold and drier conditions in winter. 
The annual average precipitation is about $1800 \mathrm{~mm}$, and the annual average temperature is about $18{ }^{\circ} \mathrm{C}[31,32]$. The terrain is high in the north and low in the south, and the water system in the river basin is fan-shaped. Floods may easily arise at the confluence of the river systems during heavy rainfall. Carbonate rocks in the basin are widely distributed, forming a typical Karst topography that accentuates droughts and floods in the basin [33]. As a result of the floods and droughts, the study of hydrological processes in this basin has become especially important.

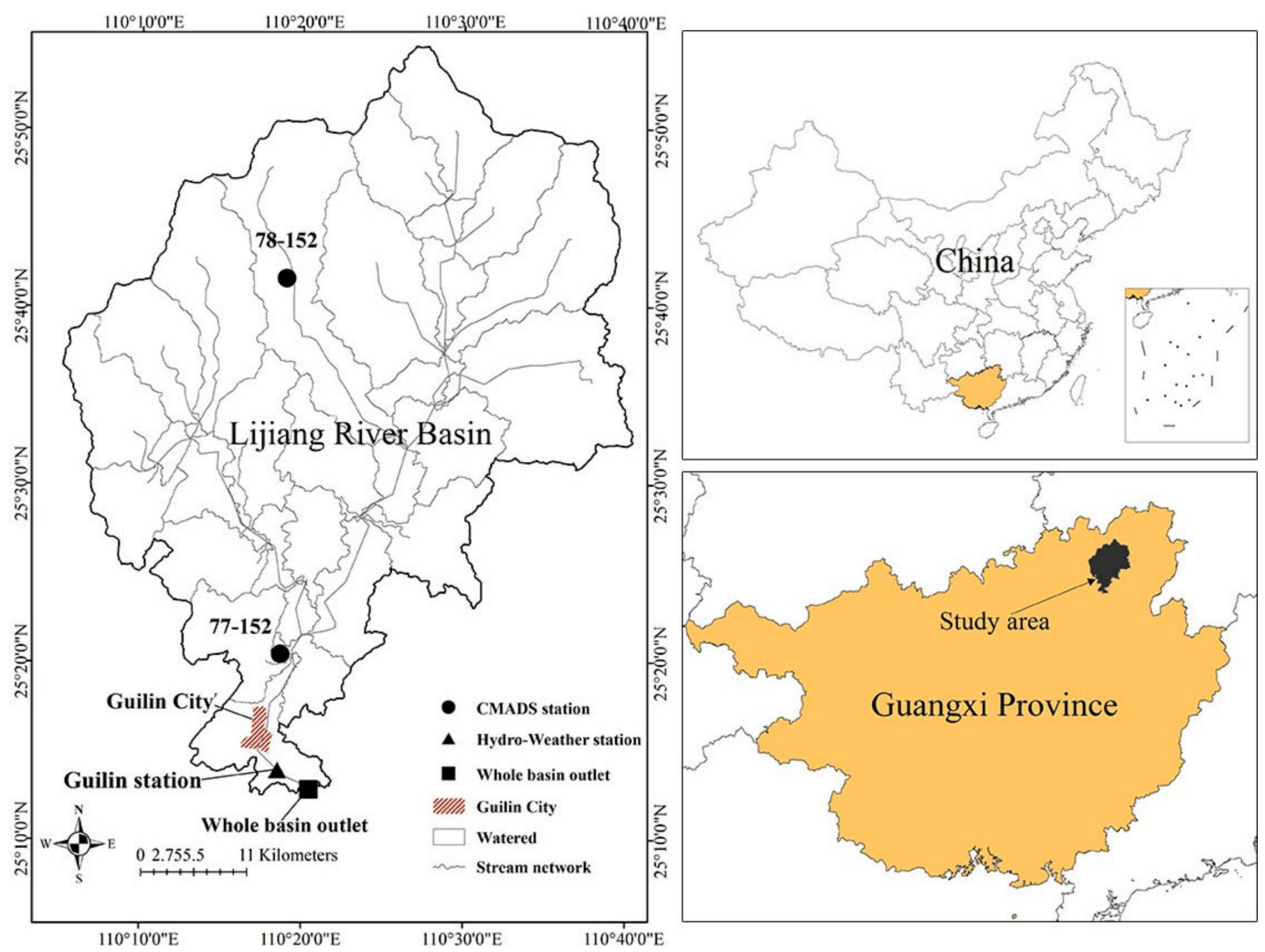

Figure 1. The location of the study area in China.

Guilin City is located in the lower reaches of the fan-shaped watershed, and in 2016 had a population of about 5.34 million and an urban area of $27,800 \mathrm{~km}^{2}$. In recent years, heavy rainfall in the Lijiang River Basin has led to flood disasters in Guilin, resulting in huge losses of life and property. The section of the Lijiang River that flows though Guilin City was selected as the study area. The study area covers $2531 \mathrm{~km}^{2}$, and accounts for about $42 \%$ of the total basin area.

\subsection{SWAT Model Input}

The Guilin Hydrological Station was used as the whole outlet. The SWAT 2012 version was used to divide the basin into 33 sub-basins and 355 hydrological response units. The basic data needed for the model included topography, soil, land use, and meteorological data. The data are presented in Table 1:

(i) The digital elevation model used is the first version of the Advanced Spaceborne Thermal Emission and Reflection Radiometer (ASTER) Global Digital Elevation Model (GDEM) (grid cell: $30 \mathrm{~m} \times 30 \mathrm{~m}$ ). The outliers have been processed, and the original Digital Elevation Model (DEM) has been spliced, cropped, and projected using ArcMAP (ESRI, Redlands, CA, America) software. Sub-watershed divisions, river formation, and slope reclassification were all generated from the pre-treated DEM. 
(ii) The soil data were taken from the 1:1 million soil dataset created by the Second National Land Survey Nanjing Soil Institute and were supplied by the Cold and Arid Regions Sciences Data Center at Lanzhou.

(iii) The land use data were derived from Landsat- 8 remote sensing data (multi-spectral band resolution of $30 \mathrm{~m}$ ) after supervised classification and post-processing steps. The remote sensing data were provided by the Geospatial Data Cloud site, the Computer Network Information Center, the Chinese Academy of Sciences.

(iv) The meteorological data are taken from the CMADS version 1.1 (http:/ / www.cmads.org). This dataset includes precipitation, temperature, relative humidity, solar radiation, wind speed, location, and the elevation of each site. The data of temperature, relative humidity and wind speed were generated using the information from 2421 national automatic stations and 39,439 regional automatic stations. Precipitation was achieved through the integration of multiple satellite data and precipitation from ground automatic stations. The production of radiation data was based on the Discrete Ordinates Radiative Transfer (DISORT) radiative transfer model and the acquisition of products from the FY2E satellite primary product for inversion of solar shortwave radiation. Two CMADS weather stations are used in the study area.

(v) The hydrological data were provided by the Guangxi Water Conservancy, and comprise measured daily and monthly data from 2008 to 2016 at the Guilin Hydrological Station.

Table 1. Data description for the study area.

\begin{tabular}{ccc}
\hline Data Type & Source & Spatial Resolution \\
\hline DEM & ASTER GDEM https://earthexplorer.usgs.gov/ & $30 \mathrm{~m}$ \\
Land use & Landsat-8 https://earthexplorer.usgs.gov/ & $30 \mathrm{~m}$ \\
Soil & HWSD http://westdc.westgis.ac.cn/data/ & $30 \mathrm{~m}$ \\
Weather & CMADS version 1.1 http://www.cmads.org/ & $28 \mathrm{~km}$ \\
\hline
\end{tabular}

The SWAT database was constructed using CMADS meteorological data, DEM, and land use and soil data (Figure 2). Daily and monthly scale simulations of the hydrological processes in the Lijiang River Basin were conducted using the measured data from the Guilin Hydrological Station. The model calibration included a 1 year warm-up period (2008), and then the calibration was performed for a period of 2 years (2009-2010), followed by a validation period of 6 years (2011-2016). The simulation results were evaluated using the NSE, $\mathrm{R}^{2}$, and PBIAS.

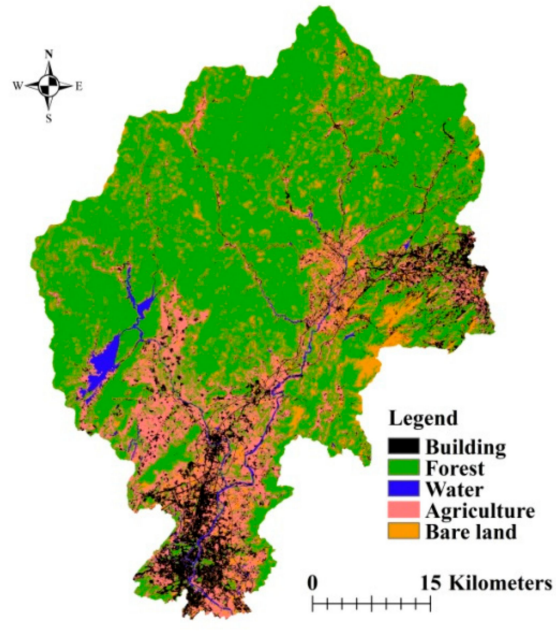

(a)

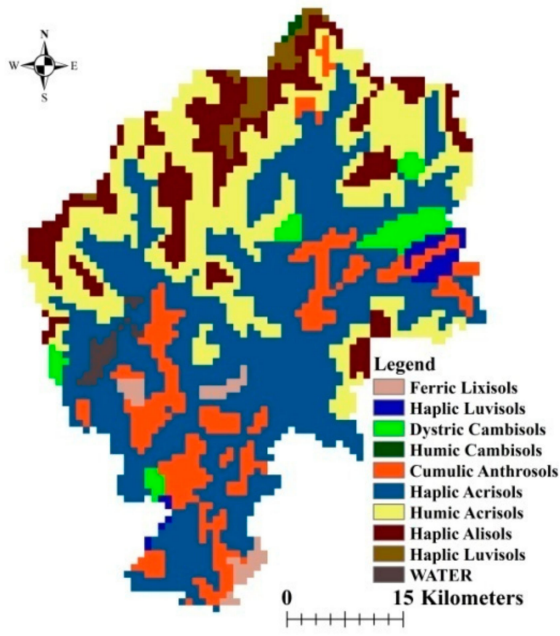

(b)

Figure 2. (a) Land use data; (b) Soil data. 


\section{Results and Analysis}

\subsection{Model Calibration and Validation}

The Computer Program for Calibration of Soil and Water Assessment Tool Models (SWAT-CUP) software SUFI-2 algorithm was used to calibrate and validate the model. SWAT-CUP is a program that does automatic calibration and uncertainty analysis, and was developed by EWAGE research institute for the SWAT model [34]. The SUFI-2 algorithm uses an inversion modeling method that defines a large range of parameters and then performs multiple iterations. By comparing the results of each iteration, the most suitable parameter range of the model is determined, and uncertainty analysis is conducted by evaluating the range results for each parameter [35]. SUFI-2 is an iterative procedure that accounts for parameter uncertainty from all kinds of sources (e.g., weather, model parameters, and model structure). It provides a comprehensive optimization and uncertainty analysis through the global search method [36]. The calibration and validation of the modeled simulation results are needed for the satisfactory assessment of watershed characteristics.

There are many parameters in SWAT-CUP that affect the simulation of the hydrological cycle. Choosing appropriate parameters can play a crucial role in determining the effectiveness of the calibration. After comparing the efficiency of each parameter, we chose 8 parameters for the monthly simulation, and 13 parameters for the daily simulation (Tables 2 and 3 ).

Table 2. Ranking of the most sensitive parameters and their monthly simulation variation ranges.

\begin{tabular}{cccccccc}
\hline Parameter Name & Description & Min & Max & Value Adopted & \multicolumn{3}{c}{ Calibration } \\
\cline { 5 - 7 } R_OV_N & $\begin{array}{c}\text { Manning's “n” value for } \\
\text { overland flow }\end{array}$ & 10.00 & 20.00 & 17.25 & -2.68 & 0.02 & 1 \\
\hline V__ALPHA_BF & $\begin{array}{c}\text { Baseflow alphat factor } \\
\text { (days) }\end{array}$ & 0.00 & 0.50 & 0.41 & 2.48 & 0.03 & 2 \\
\hline R_CN2 & $\begin{array}{c}\text { SCS runoff curve number } \\
\text { for moisture condition II }\end{array}$ & 0.00 & 0.60 & 0.41 & 1.57 & 0.14 & 3 \\
\hline V_CH_K2 & $\begin{array}{c}\text { Effective hydraulic } \\
\text { conductivity in main } \\
\text { channel alluvium }\end{array}$ & 100.00 & 150.00 & 131.25 & -1.25 & 0.24 & 4 \\
\hline V_GWQMN & $\begin{array}{c}\text { Treshold depth of water } \\
\text { in the shallow aquifer } \\
\text { required for return flow } \\
\text { to occur (mm) }\end{array}$ & 0.00 & 3.00 & 2.63 & -0.45 & 0.66 & 5 \\
\hline R_ESCO & $\begin{array}{c}\text { Soil evaporation } \\
\text { compensation factor }\end{array}$ & 0.00 & 0.80 & 0.30 & 0.41 & 0.69 & 6 \\
\hline R_SOL_AWC(1) & $\begin{array}{c}\text { Available water capacity } \\
\text { of the soil layer }\end{array}$ & 0.00 & 0.60 & 0.11 & -0.31 & 0.76 & 7 \\
\hline V_GW_DELAY & $\begin{array}{c}\text { Groundwater delay } \\
\text { (days) }\end{array}$ & 0.00 & 170.00 & 46.75 & 0.04 & 0.97 & 8 \\
\hline
\end{tabular}

Table 3. Ranking of the most sensitive parameters and their daily simulation variation ranges.

\begin{tabular}{|c|c|c|c|c|c|c|c|}
\hline \multirow{2}{*}{ Parameter Name } & \multirow{2}{*}{ Description } & \multirow{2}{*}{ Min } & \multirow{2}{*}{ Max } & \multirow{2}{*}{ Value Adopted } & \multicolumn{3}{|c|}{ Calibration } \\
\hline & & & & & t-Stat & $p$-Value & Rank \\
\hline $\mathrm{R} \_\mathrm{CN} 2$ & $\begin{array}{l}\text { SCS runoff curve number } \\
\text { for moisture condition II }\end{array}$ & -0.30 & 0.01 & -0.17 & 8.77 & 0.00 & 1 \\
\hline R_HRU_SLP & Average slope steepness & -0.98 & 0.10 & -0.35 & 6.08 & 0.00 & 2 \\
\hline $\mathrm{R} \_S O L \_K(1)$ & $\begin{array}{l}\text { Saturated hydraulic } \\
\text { conductivity }\end{array}$ & 0.00 & 5.00 & 0.03 & -4.99 & 0.00 & 3 \\
\hline
\end{tabular}


Table 3. Cont.

\begin{tabular}{|c|c|c|c|c|c|c|c|}
\hline \multirow{2}{*}{ Parameter Name } & \multirow{2}{*}{ Description } & \multirow{2}{*}{ Min } & \multirow{2}{*}{ Max } & \multirow{2}{*}{ Value Adopted } & \multicolumn{3}{|c|}{ Calibration } \\
\hline & & & & & t-Stat & $p$-Value & Rank \\
\hline V_RCHRG_DP & $\begin{array}{l}\text { Deep aquifer percolation } \\
\text { fraction }\end{array}$ & 0.10 & 0.40 & 0.15 & -3.65 & 0.00 & 4 \\
\hline V_GW_DELAY & $\begin{array}{l}\text { Groundwater delay } \\
\text { (days) }\end{array}$ & 0.00 & 2.00 & 0.17 & -3.14 & 0.00 & 5 \\
\hline V_OV_N & $\begin{array}{l}\text { Manning's " } n \text { " value for } \\
\text { overland flow }\end{array}$ & 3.00 & 6.00 & 5.47 & -2.55 & 0.01 & 6 \\
\hline V_ALPHA_BF & $\begin{array}{l}\text { Baseflow alpha factor } \\
\text { (days) }\end{array}$ & 0.10 & 0.20 & 0.16 & 2.50 & 0.01 & 7 \\
\hline V_GWQMN & $\begin{array}{l}\text { Treshold depth of water } \\
\text { in the shallow aquifer } \\
\text { required for return flow } \\
\text { to occur }(\mathrm{mm})\end{array}$ & 10.00 & 500.00 & 46.75 & -2.40 & 0.02 & 8 \\
\hline $\mathrm{R} \_\mathrm{SOL} \_\mathrm{Z}(1)$ & $\begin{array}{l}\text { Depth from soil surface to } \\
\text { bottom of layer }\end{array}$ & -0.25 & 0.25 & -0.11 & 1.52 & 0.13 & 9 \\
\hline $\mathrm{V} \_\mathrm{CH}$ _K2 & $\begin{array}{l}\text { Effective hydraulic } \\
\text { conductivity in main } \\
\text { channel alluvium }\end{array}$ & 0.00 & 220.00 & 212.30 & 1.14 & 0.25 & 10 \\
\hline V_REVAPMN & $\begin{array}{l}\text { Threshold depth of water } \\
\text { in the shallow aquifer for } \\
\text { "revap" to occur (mm) }\end{array}$ & 0.00 & 500.00 & 367.5 & -0.65 & 0.51 & 11 \\
\hline R_SOL_AWC(1) & $\begin{array}{l}\text { Available water capacity } \\
\text { of the soil layer }\end{array}$ & 0.20 & 0.40 & 0.21 & 0.58 & 0.55 & 12 \\
\hline R_ESCO & $\begin{array}{l}\text { Soil evaporation } \\
\text { compensation factor }\end{array}$ & 0.00 & 0.10 & 0.04 & 0.46 & 0.64 & 13 \\
\hline
\end{tabular}

The results for the evaluation index after the model runs are shown in Table 4. Previous research results show that if $R^{2}$ and NSE are close to 1 , then the simulated value of the model is close to the true value. PBIAS is also used as a model evaluation criteria, and an absolute value of less than 10 is usually considered a good result [37]. In the monthly simulation, $\mathrm{R}^{2}$ and NSE were both 0.96 during the calibration period, while $\mathrm{R}^{2}$ was 0.96 and NSE was 0.95 during the validation period. PBIAS was less than 10 during the calibration and the validation period. Figure 3 shows the results calculated for the monthly simulated and observed values. The figure shows that the trend and values of the simulated results are very close to the measured results. The figure also shows that runoff characteristics (large summer runoff and a small winter runoff) of the Lijiang River Basin are similar to those found in most regions with a monsoon climate. It is noteworthy that there was a large peak in the Lijiang River runoff in November 2015. This was the result of a rare winter storm in Guilin. Figure 4 shows the calculated results of the daily simulated and observed values. In the daily simulation, $\mathrm{R}^{2}$ was 0.92 for the calibration period and 0.89 for the validation period. NSE values for the calibration period were 0.89 and 0.88 , respectively, and the corresponding PBIAS values were 20.70 and 14.40 , respectively. Thus, good daily simulation results were obtained. It can be concluded that the SWAT model, driven by CMADS meteorological data, provided good results for the Lijiang River Basin in Guangxi Province, and the data set and model can be used to further study hydrological processes in this basin. 
Table 4. Performance statistics for the flow simulations.

\begin{tabular}{ccc}
\hline Object & Calibration (2009-2010) & Validation (2011-2016) \\
\hline P-factor (Monthly) & 0.79 & 0.63 \\
R-factor (Monthly) & 0.33 & 0.37 \\
R $^{2}$ (Monthly) & 0.96 & 0.96 \\
NSE (Monthly) & 0.96 & 0.95 \\
PBIAS (Monthly) & 7.70 & 7.80 \\
RSR (Monthly) & 0.20 & 0.22 \\
P-factor (Daily) & 0.70 & 0.77 \\
R-factor (Daily) & 0.30 & 0.43 \\
R (Daily) & 0.92 & 0.89 \\
NSE (Daily) & 0.89 & 0.88 \\
PBIAS (Daily) & 20.70 & 14.40 \\
RSR (Daily) & 0.33 & 0.35 \\
\hline
\end{tabular}

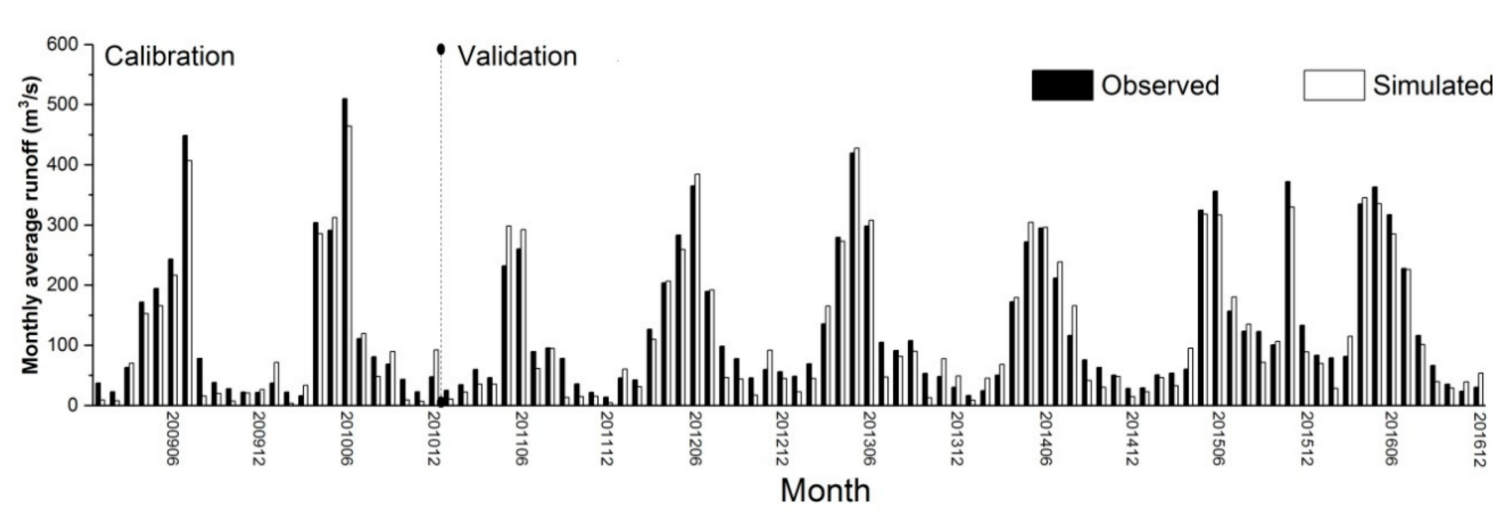

Figure 3. Comparison of monthly runoff using Soil and Water Assessment Tool (SWAT).

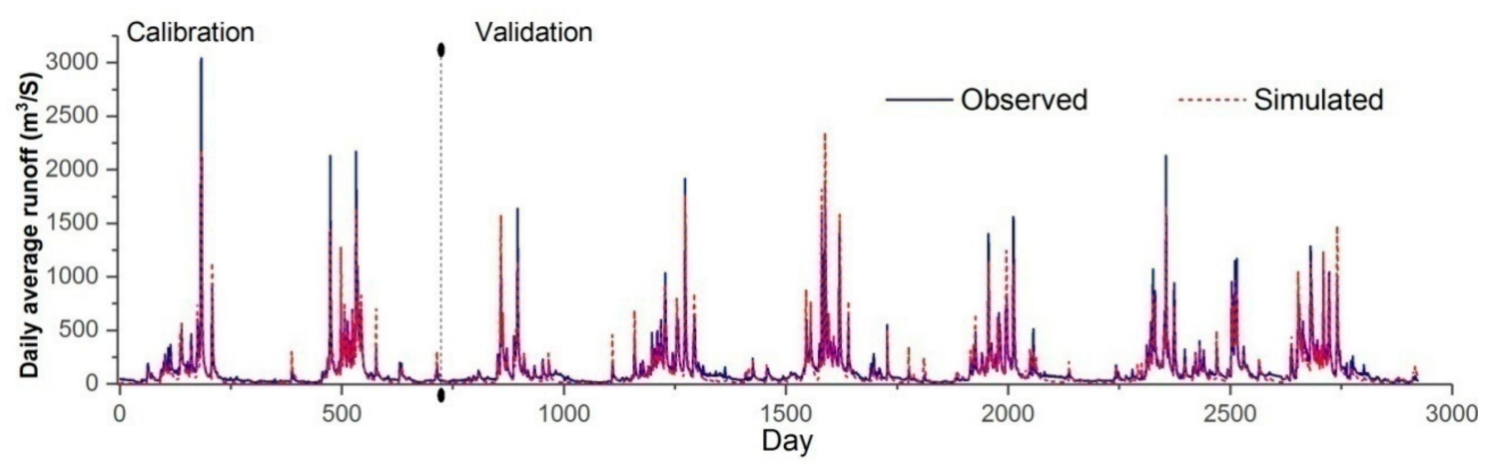

Figure 4. Comparison of daily runoff using SWAT.

\subsection{Uncertainty Analysis}

The SUFI-2 algorithm was iterated three times, with each calibration and validation iteration running 100 times. The R-factor and P-factor are important indicators for evaluating the uncertainty of simulation results. It is generally assumed that the closer the R-factor is to 0 and the closer the P-factor is 1 , the closer the simulation results are to the measured data, and the lower the uncertainty in the model results [38]. Table 3 shows that in the runoff simulation of the Guilin sites, both the R-factor and the P-factor had reached optimal values in the calibration and validation periods, thus indicating that the uncertainty in the simulation results was small.

In addition, the correlation between parameters is an indicator of their redundancy. Figure 5 shows the relationship between the parameters and also the relationship between the parameters and the objective function using the NSE. The correlation between most of the parameters was very 
small, indicating that the redundancy was small in the parameterization for the Lijiang River Basin. The relationship between the NSE and the parameters in Figure 5, shows that the NSE was always above 0.7 , and usually higher than 0.8. In the areas with a high NSE, there are many parameters exhibiting the equifinality phenomenon. These characteristics also indicate that most of the parameters from the model simulation results have a low uncertainty. It should be noted that the degree of aggregation of NSE decreases as the value of the curve number for moisture condition II (CN2) decreases, indicating that $\mathrm{CN} 2$ has a greater influence on the uncertainty of the simulation results. Parameter CN2 is associated with soil permeability, land use, and initial soil water condition, and indicates the potential for surface runoff from precipitation in a river basin. To take into account the important impact of CN2 on the hydrological elements of surface runoff, we chose relatively stable values in the $-0.3-0.01$ range for the final values of $\mathrm{CN} 2$.

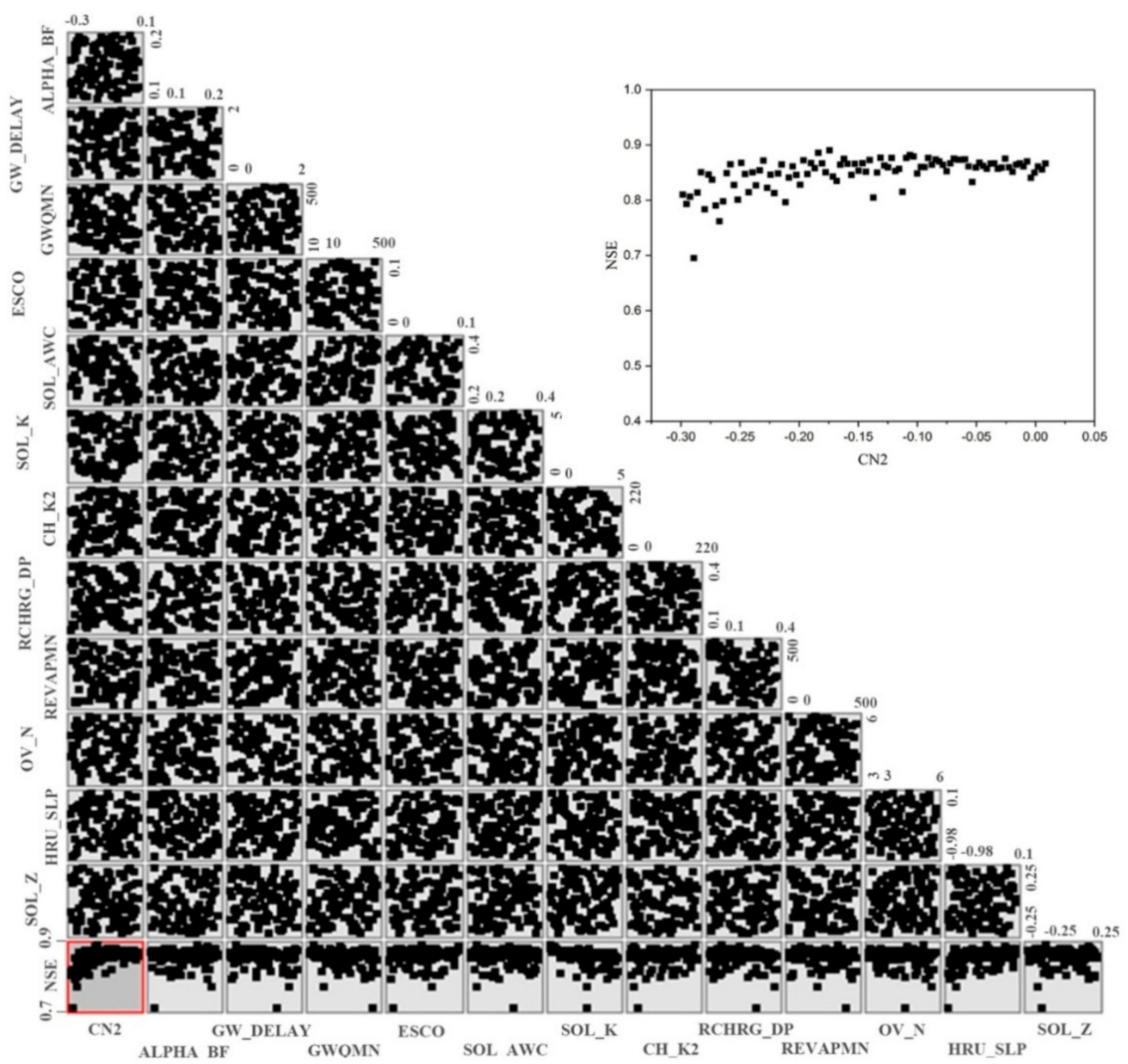

Figure 5. Pair-wise correlations between parameters, and correlations between parameters and Nash-Sutcliffe model efficiency coefficient (NSE).

To show the results of the operation of the SUFI-2 algorithm, we used kernel smoothing to represent the distribution of NSE. Figure 6 shows that the NSE values for each simulation are larger than the SUFI-2 algorithm's default value of 0.5. Most of the values were concentrated between 0.82-0.87. These distributions show that the SUFI-2 algorithm performed well, and that the uncertainty in the model results was low. 


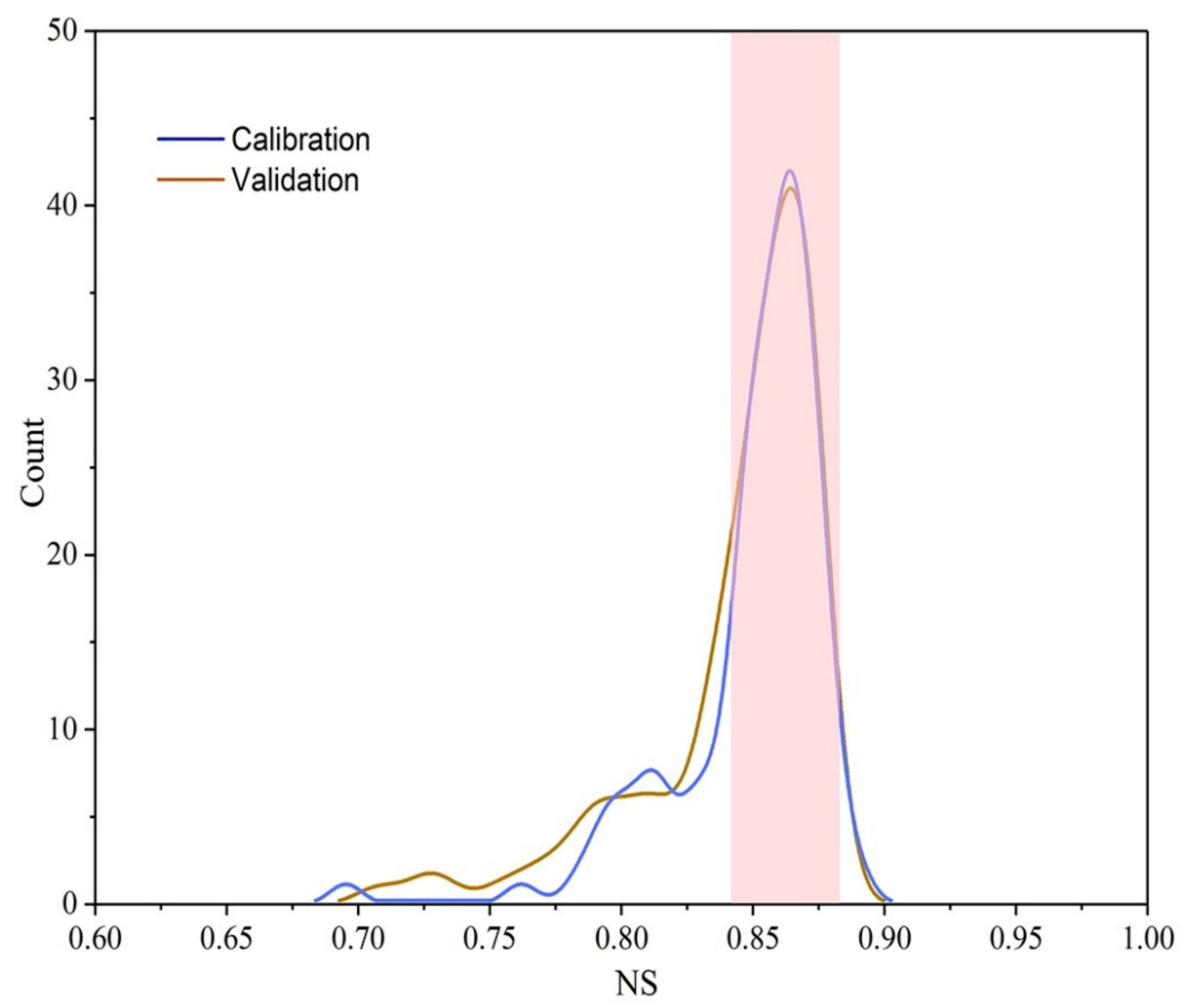

Figure 6. Kernel smoothing fit of the distribution of NSE.

\subsection{Water Balance Components}

The SWAT model often overestimates or underestimates some elements of hydrological budgets. Calibration ensures that the simulated values are closer to the observed values, and also ensures that the hydrological elements are in a reasonable range. Table 5 shows the average annual contributions to the water budget for the main hydrological elements. From 2009-2016, the average annual precipitation was up to $2150.20 \mathrm{~mm}$. The average annual values of surface runoff, evapotranspiration (ET), lateral flow, and shallow groundwater in the Lijiang River Basin were $518.36 \mathrm{~mm}, 750.60 \mathrm{~mm}, 129.21 \mathrm{~mm}$, and $555.34 \mathrm{~mm}$, respectively. Figure 7 shows the average annual values of the hydrological elements as a relative percentage of precipitation for uncalibrated and calibrated periods. The figure shows that the percentage of deep aquifer recharge, deep aquifer flow, shallow aquifer flow, and lateral flow increased. Actual ET and surface runoff decreased. In the calibration period, ET caused major water losses, and the average proportion of ET to precipitation was $34.9 \%$ per year. The low latitude and high temperature of the basin location contributed to the high ET, and the wide distribution of agriculture further increased the ET. The average annual contribution of lateral flow as a relative percentage of precipitation was $6.0 \%$. Shallow groundwater flow to streamflow accounted for $25.8 \%$ of precipitation. Deep aquifer recharge accounted for $8.8 \%$ of the total precipitation.

It was possible to view the variation in the model's output across the basin. Figure 8 shows the spatial distribution of precipitation, actual ET, surface runoff contribution to streamflow, and groundwater contribution to streamflow during the study period. When the spatial distribution of ET (Figure 8) and land use (Figure 2) are compared, it can be seen that the lake area and the agricultural area have high ET values. The distribution of surface runoff contribution to streamflow, and of groundwater contribution to streamflow, is related to precipitation. There is more precipitation in the northern part of the basin and less precipitation in the south. The contribution of surface runoff and groundwater to streamflow in the sub-basins upstream is also consistent with the spatial distribution of precipitation in the basin that was studied. 
Table 5. Average annual contribution by the hydrological elements to the water budget.

\begin{tabular}{|c|c|c|}
\hline \multicolumn{2}{|c|}{ Hydrological Elements } & Calibration \\
\hline \multicolumn{2}{|c|}{ Precipitation } & $2150.20 \mathrm{~mm}$ \\
\hline \multicolumn{2}{|c|}{ Surface runoff } & $518.36 \mathrm{~mm}$ \\
\hline \multicolumn{2}{|c|}{ Lateral flow } & $129.21 \mathrm{~mm}$ \\
\hline \multicolumn{2}{|c|}{ Shallow groundwater contribute to streamflow } & $555.34 \mathrm{~mm}$ \\
\hline \multicolumn{2}{|c|}{ Deep groundwater contribute to streamflow } & $188.62 \mathrm{~mm}$ \\
\hline \multicolumn{2}{|c|}{ Total aquifer recharge } & $746.08 \mathrm{~mm}$ \\
\hline \multicolumn{2}{|c|}{ Deep groundwater recharge } & $189.88 \mathrm{~mm}$ \\
\hline \multicolumn{2}{|c|}{ Water yield } & $1391.51 \mathrm{~mm}$ \\
\hline \multicolumn{2}{|c|}{ Evapotranspiration } & $750.6 \mathrm{~mm}$ \\
\hline \multicolumn{3}{|c|}{$\begin{array}{lll}\text { Deep aquifer recharge } & 1.1 \% & \\
& & 8.8 \%\end{array}$} \\
\hline Gw deep aquifer $Q$ & \multicolumn{2}{|l|}{$1.1 \%$} \\
\hline Gw shallow aquifer $Q$ & \multicolumn{2}{|l|}{$19.8 \%$} \\
\hline Potential ET & \multicolumn{2}{|r|}{$\begin{array}{l}51.4 \% \\
51.4 \%\end{array}$} \\
\hline Actual ET & \multicolumn{2}{|c|}{$\begin{array}{l}36.3 \% \\
34.9 \%\end{array}$} \\
\hline Lateral flow & \multicolumn{2}{|l|}{$\begin{array}{l}4.3 \% \\
6.0 \%\end{array}$} \\
\hline Surface runoff & \multicolumn{2}{|c|}{$36.9 \%$} \\
\hline
\end{tabular}

Figure 7. Average annual values of hydrological elements as a percentage of precipitation for pre- and post-calibration periods.

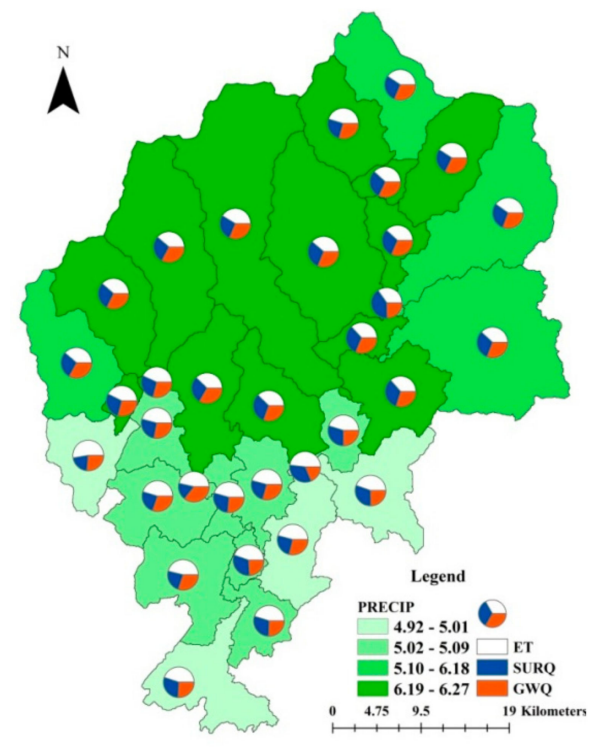

Figure 8. Spatial distribution of actual evapotranspiration (ET), surface runoff, groundwater discharge, and precipitation for the study period.

Figure 9 shows the variation in the contribution to the water budget by the main hydrological elements in the Lijiang River Basin from 2009-2016. The contribution to the water budget by groundwater discharge, lateral flow, and surface runoff decreased significantly in 2011, which was a dry year. The contributions by groundwater, lateral flow, and surface runoff reached their highest 
values in 2015, which was a flood year. The annual changes in the contributions by the different components of the water budget are consistent with the annual changes in precipitation. The change rates for surface runoff, lateral flow, and groundwater discharge decreased the most in 2011, and increased the most in 2012. The contribution by surface runoff decreased by about $38.4 \%$ in $2010-2011$ and increased by $80.0 \%$ in $2011-2012$. The contribution by lateral flow decreased by about $28.8 \%$ in $2010-2011$ and increased by $56.4 \%$ in 2011-2012. The contribution by groundwater decreased by about $39.4 \%$ in $2010-2011$ and increased by $81.9 \%$ in 2011-2012. It is worth noting that contributions to the water budget may be carried over from year to year. For example, precipitation in 2012 was more than in 2013, but surface runoff in 2012 was less than in 2013. The water balance in 2012 may have been affected by the drought in the previous year. However, there was no significant change in ET, which remained stable during the calibration and validation periods. The average annual change rate for ET was only about $1.6 \%$.

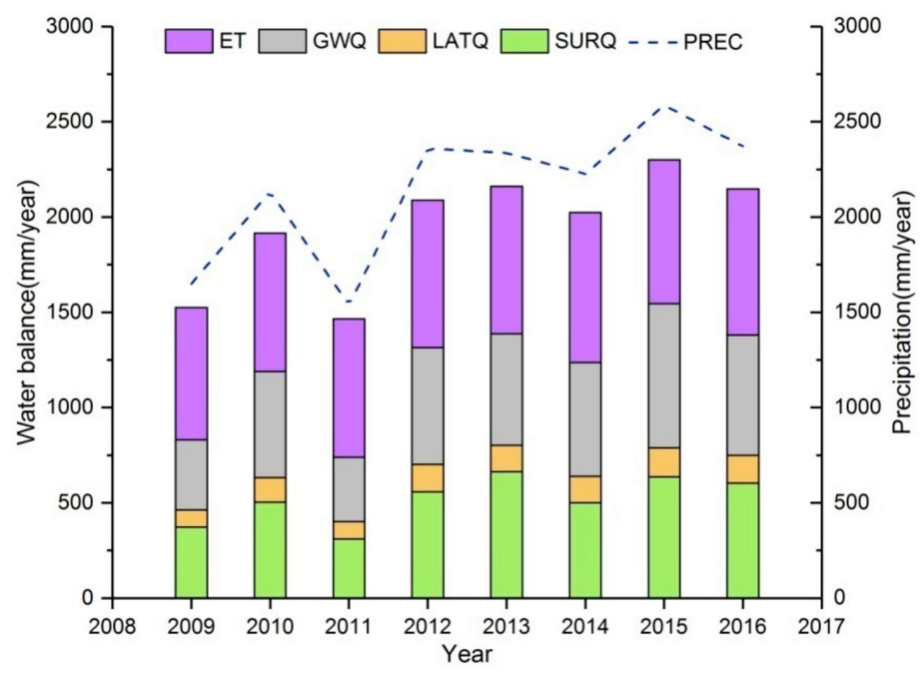

Figure 9. Annual change in contribution by the hydrological elements to the water budget.

Figure 10 shows the variation in each element of the water balance at a monthly scale. ET was an important loss in the basin water balance, and its change shows clear seasonal variations. There was little ET in winter and high ET in summer. The seasonal variation in surface runoff, lateral flow, and groundwater discharge was consistent with the change in precipitation. The proportion of surface flow to precipitation was $0.1-40.4 \%$ at the monthly scale, and there was a noticeable difference between the winter and summer percentages. The proportion of lateral flow to precipitation was $4.2-21.7 \%$. Lateral flow was a large proportion of precipitation in summer and a small proportion in winter. The groundwater discharge was also consistent with changes in the precipitation. The proportion of groundwater discharge to precipitation varies widely between summer and winter.

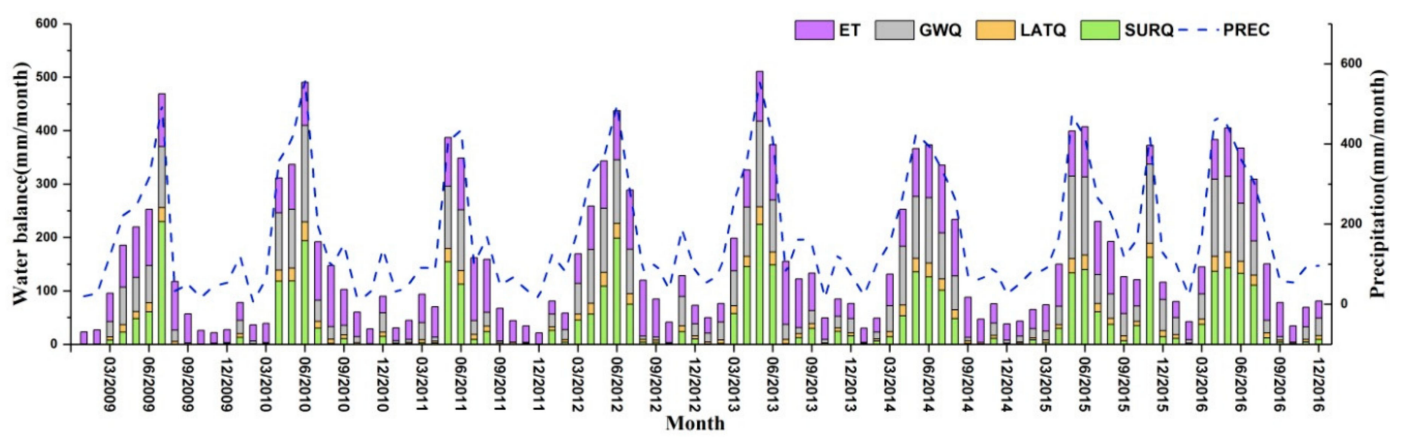

Figure 10. Monthly change in the contribution by the hydrological elements to the water budget. 
The relationship between each water balance element and precipitation is shown in Figure 11. The correlation between the contribution of each hydrological element and precipitation was analyzed separately. In addition, the P-value is less than 0.01 in the significance test of precipitation and these hydrological elements. Precipitation has an important influence on surface runoff. The surface flow and precipitation in the Lijiang River Basin maintained a curvilinear relationship with a $R^{2}$ of 0.903 . This relationship between surface runoff and precipitation implies that high precipitation is likely to rapidly increase surface runoff and cause floods in the Lijiang River Basin. Lateral runoff and precipitation maintained a linear correlation, with a $R^{2}$ of 0.971 . The relationship between groundwater discharge and precipitation was also analyzed, and a $\mathrm{R}^{2}$ of 0.926 was obtained. The relationship between ET and precipitation in summer and winter was also analyzed. The correlation between ET and precipitation in summer was 0.153 . The correlation between ET and precipitation in winter was 0.094. The results show that there was no significant relationship between ET and precipitation in the Lijiang River Basin.

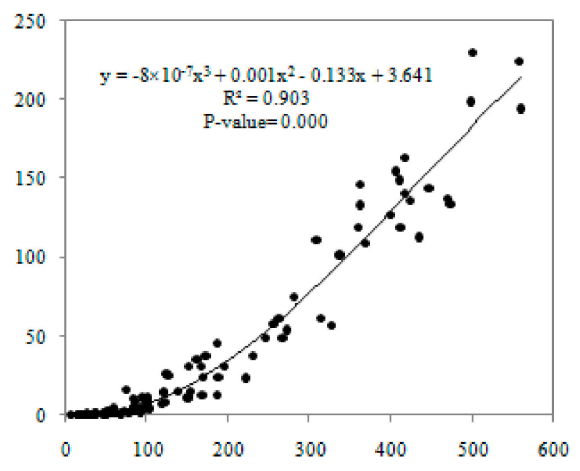

(a)

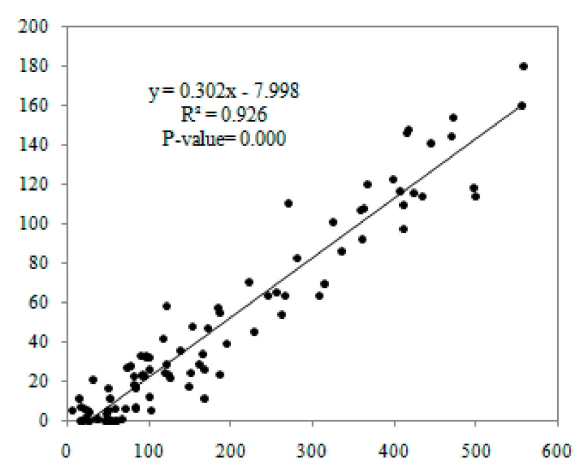

(c)

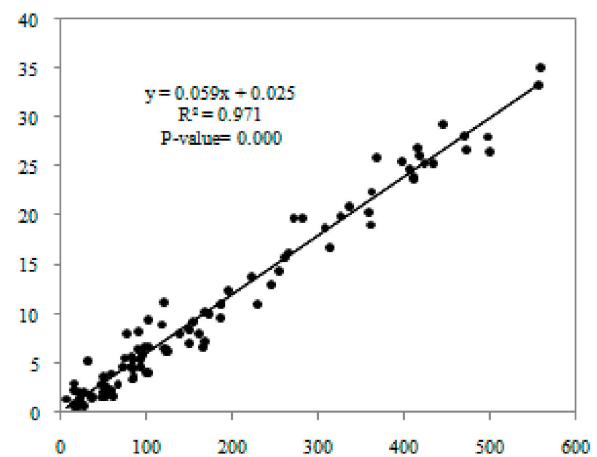

(b)

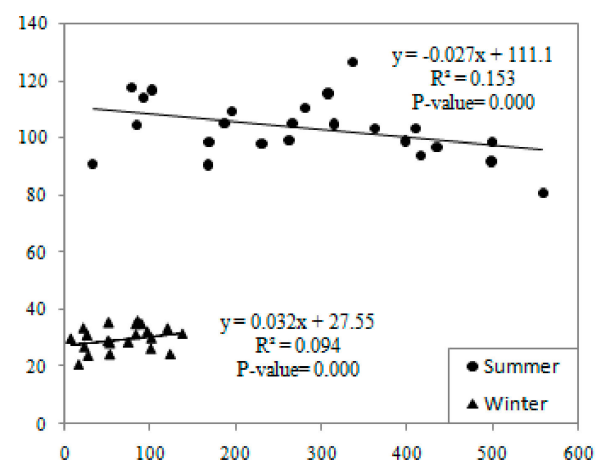

(d)

Figure 11. Regression analysis results for the hydrological elements and precipitation. (a) Surface flow and precipitation; (b) Lateral runoff and precipitation; (c) Groundwater discharge and precipitation; (d) ET and precipitation.

\section{Conclusions}

The present study used CMADS data and the SWAT model to successfully generate daily and monthly scale runoff simulations for the Lijiang River Basin. The analysis of pair-wise correlations between the parameters shows that the redundancy was small in the parameterization. Both the R-factor and P-factor reached ideal values in the calibration and validation periods, which indicated that there was low uncertainty in the simulation results and model parameters.

Using the model's output, the average annual contribution to the water budget by hydrological elements was analyzed. From 2009-2016, the average annual value of surface runoff, ET, lateral flow, and shallow groundwater in the Lijiang River Basin were 518.36 mm, 750.60 mm, $129.21 \mathrm{~mm}$, 
$555.34 \mathrm{~mm}$, respectively. The spatial distribution of surface runoff and groundwater discharge was related to precipitation. The highest ET values were obtained in the west of the basin, where agriculture is prevalent. The water budget of groundwater discharge, lateral flow, and surface runoff reached the highest values in the flood year, and reached the lowest values in the driest year. The high correlation between these elements and precipitation was reflected in the regression analysis. ET remained stable during the calibration and validation period. The results for the hydrological elements could provide valuable reference information for water resources management in the Lijiang River Basin.

Author Contributions: The modeling and writing of this work by Y.C.; J.Z. designed the experiments; Observed data was provided by M.Y. and Z.Z.; The improvement of manuscript writing by J.Z., B.G., L.Y., J.Q. and X.L.

Acknowledgments: This work is supported by National Key R\&D Program of China (2017YFC0406004), NSFC (41271004) and the project of Ecological Dispatching Technology of Flood Prevention in Guilin City and Lijiang River Replenishment Reservoir (GXZC2016-G3-2344-JHZJ; AB16380313).

Conflicts of Interest: The authors declare no conflicts of interest.

\section{References}

1. Meng, X.; Wang, H.; Wu, Y.; Long, A.; Wang, J.; Shi, C.; Ji, X. Investigating spatiotemporal changes of the land-surface processes in Xinjiang using high-resolution CLM3.5 and CLDAS: Soil temperature. Sci. Rep. 2017, 7, 13286. [CrossRef] [PubMed]

2. Meng, X.; Sun, Z.; Zhao, H.; Ji, X.; Wang, H.; Xue, L.; Wu, H.; Zhu, Y. Spring flood forecasting based on the WRF-TSRM mode. Teh. Vjesn. 2018, 25, 141-151. [CrossRef]

3. Allen, M.R.; Ingram, W.J. Constraints on future changes in climate and the hydrologic cycle. Nature 2002, 419, 224-232. [CrossRef] [PubMed]

4. Sandra, G.; Sathian, K.K. Assessment of water balance of a watershed using swat model for water resources management. Int. J. Eng. Sci. Res. Technol. 2016, 5, 177-184. [CrossRef]

5. Arnold, J.G.; Allen, P.M. Estimating hydrologic budgets for three Illinois watersheds. J. Hydrol. 1996, 176, 57-77. [CrossRef]

6. Zhang, J.; Li, Q.; Guo, B.; Gong, H. The comparative study of multi-site uncertainty evaluation method based on SWAT model. Hydrol. Process. 2015, 29, 2994-3009. [CrossRef]

7. Arnold, J.G.; Srinivasan, R.; Muttiah, R.S.; Williams, J.R. Large area hydrologic modeling and assessment. Part I: Model development. J. Am. Water Resour. Assoc. 1998, 34, 73-89. [CrossRef]

8. Sophocleous, M.A.; Koelliker, J.K.; Govindaraju, R.S. Integrated numerical modeling for basin-wide water management: The case of the Rattlesnake Creek basin in south-central Kansans. J. Hydrol. 1999, 214, 179-196. [CrossRef]

9. Eckhardt, K.; Haverkamp, S.; Fohrer, N.; Frede, H.G. SWAT-G, a version of SWAT99.2 modified for application to low mountain range catchments. Phys. Chem. Earth 2002, 27, 641-644. [CrossRef]

10. Eckhardt, K.; Nicola, F.; Frede, H.G. Automatic model calibration. Hydrol. Process. 2005, 19, 651-658. [CrossRef]

11. Easton, Z.M.; Fuka, D.R.; Walter, M.T.; Cowan, D.M.; Schneiderman, E.M.; Steenhuis, T.S. Re-conceptualizing the Soil and Water Assessment Tool (SWAT) model to predict runoff from variable source areas. J. Hydrol. 2008, 348, 279-291. [CrossRef]

12. Meng, X.; Long, A.; Wu, Y.; Yin, G.; Wang, H.; Ji, X. Simulation and spatiotemporal pattern of air temperature and precipitation in Eastern Central Asia using RegCM. Sci. Rep. 2018, 8, 3639. [CrossRef] [PubMed]

13. Meng, X.; Yu, D.; Liu, Z. Energy balance-based SWAT model to simulate the mountain snowmelt and runoff-Taking the application in Juntanghu watershed (China) as an example. J. Mt. Sci. 2015, 12, 368-381. [CrossRef]

14. Meng, X.; Wang, H. Significance of the China Meteorological Assimilation Driving Datasets for the SWAT Model (CMADS) of East Asia. Water 2017, 9, 765-769. [CrossRef]

15. Liu, J.; Shangguan, D.; Liu, S.; Ding, Y. Evaluation and hydrological simulation of CMADS and CFSR reanalysis datasets in the Qinghai-Tibet Plateau. Water 2018, 10, 513. [CrossRef] 
16. Liu, J.; Liu, S.; Shangguan, D.; Xu, J. Applicability evaluation of precipitation datasets from CMADS, ITPCAS and TRMM 3B42 in Yurungkax River Basin. J. North China Univ. Water Res. Electr. Power 2017, 38, $28-37$. (In Chinese) [CrossRef]

17. Meng, X.; Wang, H.; Lei, X.; Cai, S.; Wu, H.; Ji, X.; Wang, J. Hydrological modeling in the Manas River Basin using soil and water assessment tool driven by CMADS. Teh. Vjesn. 2017, 24, 525-534. [CrossRef]

18. Meng, X.; Wang, H.; Cai, S.; Zhang, X.; Leng, G.; Lei, X.; Shi, C.; Liu, S.; Shang, Y. The China Meteorological Assimilation Driving Datasets for the SWAT Model (CMADS) application in China: A case study in Heihe River Basin. Available online: https: / /www.preprints.org/manuscript/201612.0091/v2 (accessed on 18 December 2016).

19. Zhao, F.; Wu, Y.; Qiu, L.; Sun, Y.; Sun, L.; Li, Q.; Niu, J.; Wang, G. Parameter uncertainty analysis of the SWAT model in a mountain-loess transitional watershed on the Chinese Loess Plateau. Water 2018, 10, 690. [CrossRef]

20. Leta, O.T.; EI-Kadi, A.I.; Dulai, H. Implications of climate change on water budgets and reservoir water harvesting of Nuuanu Area Watersheds, Oahu, Hawaii. J. Water Resour. Plan. Manag. 2017, 143. [CrossRef]

21. Cuceloglu, G.; Abbaspour, K.C.; Ozturk, I. Assessing the water-resources potential of Istanbul by using a Soil and Water Assessment Tool (SWAT) hydrological model. Water 2017, 9, 814-833. [CrossRef]

22. Zhou, G.-Y.; Wei, X.-H.; Wu, Y.-P.; Liu, S.-G.; Huang, Y.-H.; Yan, J.-H.; Zhang, D.-Q.; Zhang, Q.-M.; Liu, J.-X.; Meng, Z. Quantifying the hydrological responses to climate change using an intact forested small watershed in southern China. Glob. Chang. Biol. 2011, 17, 3736-3746. [CrossRef]

23. Wu, Y.-P.; Liu, S.-G.; Yan, W.-D.; Xia, J.-Z.; Xiang, W.-H.; Wang, K.-L.; Luo, Q.; Fu, W.; Yuan, W.-P. Climate change and consequences on the water cycle in the humid Xiangjiang River Basin, China. Stoch. Environ. Res. Risk Assess. 2016, 30, 225-235. [CrossRef]

24. Dhami, B.; Himanshu, S.K.; Pandey, A.; Gautam, A.K. Evaluation of the SWAT model for water balance study of a mountainous snowfed river basin of Nepal. Environ. Earth Sci. 2018, 77, 1-20. [CrossRef]

25. Troin, M.; Caya, D. Evaluating the SWAT's snow hydrology over a Northern Quebec watershed. Hydrol. Process. 2014, 28, 1858-1873. [CrossRef]

26. Zhang, Y.-Q.; Luo, Y.; Sun, L.; Liu, S.-Y.; Chen, X.; Wang, X.-L. Using glacier area ratio to quantify effects of melt water on runoff. J. Hydrol. 2016, 538, 269-277. [CrossRef]

27. Golmohammadi, G.; Rudra, R.; Prasher, S. Impact of tile drainage on water budget and spatial distribution ofsediment generating areas in an agricultural watershed. Agric. Water Manag. 2017, 184, 124-134. [CrossRef]

28. Ale, S.; Bowling, L.C.; Brouder, S.M.; Frankenberger, J.R.; Youssef, M.A. Simulated effect of drainage water management operational strategy onhydrology and crop yield for Drummer soil in the Midwestern United States. Agric. Water Manag. 2009, 96, 653-665. [CrossRef]

29. Singh, R.; Helmers, M.J.; Crumpton, W.G.; Lemke, D.W. Predicting effects of drainage water management in Iowa's subsurface drained landscapes. Agric. Water Manag. 2007, 92, 162-170. [CrossRef]

30. Vu, T.T.; Li, L.; Jun, K.S. Evaluation of multi-satellite precipitation products for streamflow simulations: A case study for the Han River Basin in the Korean Peninsula, East Asia. Water 2018, 10, 642. [CrossRef]

31. Gao, M.-H.; Wu, Z.-Q.; Huang, L.-L.; Ding, Y.; Zhu, Z.-J. Length-weight relationships of 13 fish species from the Lijiang River, China. Tech. Contrib. 2018, 34, 180-182. [CrossRef]

32. Li, J.; Zhang, Y.; Qin, Q.-M.; Yan, Y.-G. Investigating the impact of human activity on land use/cover change in China's Lijiang River Basin from the perspective of flow and type of population. Sustainability 2017, 9, 383. [CrossRef]

33. Liu, G.; Jin, Q.-W.; Li, J.-Y.; Li, L.; He, C.-X.; Huang, Y.-Q.; Yao, Y.-F. Policy factors impact analysis based on remote sensing data and the CLUE-S model in the Lijiang River Basin, China. CATENA 2017, 158, $286-297$. [CrossRef]

34. Schuol, J.; Abbaspour, K.C. Using monthly weather statistics to generate daily data in a SWAT model application to West Africa. Ecol. Model. 2007, 201, 301-311. [CrossRef]

35. Abbaspour, K.C.; Genuchten, M.T.; Schulin, R.; Schlappi, E. A sequential uncertainty domain inverse procedure for estimating subsurface flow and transport parameters. Water Resour. Res. 1997, 33, 1879-1892. [CrossRef]

36. Abbaspour, K.C.; Johnson, C.A.; Van Genuchten, M.T. Estimating uncertain flow and transport parameters using a sequential uncertainty fitting procedure. Vadose Zone J. 2004, 3, 1340-1352. [CrossRef] 
37. Moriasi, D.; Arnold, J.G.; Vanliew, M.W.; Bingner, R.L.; Harmel, R.D.; Veith, T.L. Model evaluation guidelines for systematic quantification of accuracy in watershed simulations. Trans. ASABE 2007, 50, 885-900. [CrossRef]

38. Bekele, E.G.; Nicklow, J.W. Multi-objective automatic calibration of SWAT using NSGA-II. J. Hydrol. 2007, 341, 165-176. [CrossRef] 